\author{
S.M. Puzikova \\ Al-Farabi Kazakh National University, Kazakhstan, Almaty, \\ e-mail: puzikova.svetlana@inbox.ru
}

\title{
PECULIARITIES OF THE DEVELOPMENT OF SUBJECT-SUBJECT INTERACTION IN URBAN AND RURAL SCHOOLS OF KAZAKHSTAN: FINDINGS OF SOCIOLOGICAL RESEARCH OF PEDAGOGICAL PROBLEM
}

Implementation of the subject-subject approach to a child as an equal partner; development of their subjectification in the learning process is now becoming the leading factor that ensures the process democratization and modernization of the educational process, which shapes the competitiveness of not only an individual but of the kazakhstan nation, as a whole. Subject-subject interaction means the establishment of the so-called "pedagogy of cooperation", the co-management by participants in the educational process, and its democratization and humanization. An important peculiarity of the development of education in Kazakhstan is the threefold prevalence of rural schools over urban schools. As a percentage, this amounts to: $76.7 \%$ versus $23.3 \%$. The most indicative in this regard is the situation in the South Kazakhstan region, which is the most densely populated. The implementation of the subjectbased approach in school education in the region, the assessment of the degree of "modernization of public consciousness" and its ability to perceive the trends of humanization and democratization of the educational process are of scientific and practical interest in the context of fundamental reform in the educational system and Kazakhstan's search for the educational ideal.

The purpose of this article is to determine the specifics of the process of democratization in the relationships between of teachers and schoolchildren in urban and rural schools in the Republic of Kazakhstan to develop appropriate measures to improve the system and content of education.

The methodology and method of the research includes analysis of foreign and domestic publications on the development of a democratic style of interaction in the teaching and educational process, with a view to cultural characteristics, regional differences in urban and rural environments; comparative-comparative method, document analysis, survey methodologies were used, in accordance with the qualitative research strategy (questionnaires and in-depth interviews of schoolchildren and teachers).

Research Findings. Currently, the educational environment of the Republic of Kazakhstan is rethinking the process of development of competences and the system of values of the younger generation, taking into account the increasing influence of the globalization process and the value transformation in Kazakhstan's society. Proceeding from the fact that the opinions of schoolchildren and practicing teachers can suggest ways to improve the educational process while maintaining its educational potential, we have conducted a study in the target group of schoolchildren and teachers from urban and rural schools, comparing their approaches and suggestions on the development of a humanistic form of the relationship between participants in the educational process.

The study demonstrated that there is difference in how students from urban and rural schools see the factors that shape the subject-subject relationships that develop during the educational process. These features should be considered during the transformation. The author of the article focused his attention on them in this publication.

Key words: Subject-subject interactions, Modernization of education, Subjectivity of the shcoolchildren's personality, cooperation in the educational process.

\author{
С.М. Пузикова \\ Ә^-Фараби атындағы Қазақ, ұлттық университеті, Қазақстан, Алматы қ., \\ e-mail: puzikova.svetlana@inbox.ru \\ Казақстан Республикасының қалалары және ауым мектептерінің \\ сабақтық-өзарамық қызметінің дамыту программасы: педагогикамық \\ проблеманы әлеуметтанулық зерттеудің нәтижелері
}

Балаға тең құқылы серіктес ретінде субъект-пәндік қатынасты жүзеге асыру; оқу процесінде олардың субъективтілігін дамыту қазіргі уақытта жеке тұлғаның ғана емес, жалпы қазақстандық 
ұлттың бәсекеге қабілеттілігін қалыптастыратын білім беру процесін демократияландыру мен модернизациялауды қамтамасыз ететін жетекші факторға айналуда. Пәндік-пәндік өзара әрекеттесу «ынтымақтастық педагогикасы» деп аталатын құрылуды, білім беру процесіне қатысушылардың бірлесіп басқаруын және оны демократияландыру мен ізгілендіруді білдіреді. Қазақстандағы білім берудің маңызды ерекшелігі - ауыл мектептерінің қалалық мектептерден үш есе көп таралуы. Бұл пайыздық мөлшерде 23,3\%-тен 76,7\% құрайды. Осыған байланысты ең тығыз қоныстанған Оңтүстік Қазақстан облысындағы жағдай. Өңірде мектеп біліміне пәндік көзқарасты енгізу, «қоғамдық сананы жаңғырту» дәрежесін бағалау және оның білім беру процесін ізгілендіру мен демократияландыру тенденцияларын қабылАау қабілеті ғылыми және практикалық қызығушылық тудырады. Білім беру жүйесіндегі түбегейлі реформалардың контексі және Қазақстанның білім беру идеалын іздеуі.

Осы мақаяаның мақсаты - білім беру жүйесі мен мазмұнын жақсарту үшін тиісті шараларды әзірлеу үшін Қазақстан Республикасындағы қалалық және ауылдық мектептердегі мұғалімдер мен мектеп оқушыларының қарым-қатынасындағы демократияландыру процесінің ерекшеліктерін анықтау.

Зерттеудің әдістемесі мен әдісі мәдени және сыртқы ортадағы аймақтық айырмашылықтарды ескере отырып, оқу-тәрбие процесінде демократиялық өзара іс-қимылдың дамуы туралы шетелдік және отандық басылымдарға талдау жасауды; салыстырмалы-салыстырмалы әдіс, құжаттарды та^дау, зерттеу әдістері сапалы зерттеу стратегиясына сәйкес қолданылды (сауалнамалар және мектеп оқушылары мен мұғалімдердің терең сұхбаттары).

Зерттеу нәтижелері. Қазіргі уақытта Қазақстан Республикасының білім беру ортасы жаһандану процесінің және Қазақстан қоғамындағы құндылықтардың өзгеруінің өсіп келе жатқан әсерін ескере отырып, жас ұрпақтың құзыреттіліктері мен құзіреттіліктерін дамыту процесін қайта қарастыруда. Оқушылар мен практик мұғалімдердің пікірлері білім беру әлеуетін сақтай отырып, оқу процесін жақсарту жолдарын ұсына алатындығына байланысты, біз қала және ауыл мектептеріндегі оқушылар мен мұғалімдердің мақсатты тобында олардың көзқарастары мен ұсыныстарын салыстыра отырып зерттеу жүргіздік. Білім беру процесіне қатысушылар арасындағы қарым-қатынастың гуманистік формасын дамыту туралы.

Зерттеу көрсеткендей, қалалық және ауылдық мектептердегі оқушылар оқу процесінде қалыптасатын пәндік-пәндік қатынастарды қалыптастыратын фракторларды көретіндіктен айырмашылық бар. Бұл ерекшеліктер трансформация кезінде ескерілуі керек. Мақала авторы осы басылымда назарын оларға аударды.

Түйін сөздер: пәндік-өзара әрекеттестік, білім беруді модернизациялау, оқушылардың жеке басының субъективтілігі, оқу-тәрбие үрдісіндегі ынтымақтастық.

\section{С.М. Пузикова}

Казахский национальный университет им. аль-Фараби, Казахстан, г. Алматы, e-mail: puzikova.svetlana@inbox.ru

\section{Особенности развития субъектно-субъектного взаимодействия в городской и сельской школах Казахстана: выводы социологического исследования педагогической проблемы}

Настоящая статья поднимает вопрос демократизации взаимоотношений между учителем и учеником. Реализация субъект-субъектного подхода к ребенку как к равному партнеру. Развитие их субъективации в учебном процессе в настоящее время становится ведущим фактором, обеспечивающим процесс демократизации и модернизации образовательного процесса, который формирует конкурентоспособность не только отАельного человека, но и всей казахстанской нации в целом. Под субъект-субъектным взаимодействием понимается установление так называемой «педагогики сотрудничества», соуправление участниками образовательного процесса, его демократизация и гуманизация. Важной особенностью развития образования в Казахстане является трехкратное преобладание сельских школ наА городскими. В процентном отношении это составляет 76,7\% против 23,3\%. Наиболее показательным в этом отношении является ситуация в Южно-Казахстанской области, которая является наиболее густонаселенной. Внедрение предметного подхода в школьном образовании в регионе, оценка степени «модернизации общественного сознания» и его способности воспринимать тенденции гуманизации и демократизации образовательного процесса преАставляют научный и практический интерес.

Целью данной статьи является определение специфики процесса демократизации во взаимоотношениях учителей и школьников в городских и сельских школах Республики Казахстан с целью разработки соответствующих мер по совершенствованию системы и содержания образования. Методология и метод исследования включают анализ зарубежных и отечественных 
Peculiarities of the Development of Subject-Subject Interaction in Urban And Rural Schools of Kazakhstan:...

публикаций о развитии демократического стиля взаимодействия в учебно-воспитательном процессе с учетом культурных особенностей, региональных различий в городской и сельской средах, сравнительный метод, анализ документов, методики проведения опросов были использованы в соответствии со стратегией качественного исследования (анкетирование и всесторонние интервью школьников и учителей).

Результаты исследований. В настоящее время образовательная среда Республики Казахстан переосмысливает процесс развития компетенций и системы ценностей молодого поколения с учетом возрастающего влияния процесса глобализации и трансформации ценностей в казахстанском обществе. Исходя из того, что мнения школьников и практикующих учителей могут предложить пути улучшения образовательного процесса при сохранении его образовательного потенциала, мы провели исследование в целевой группе школьников и учителей из городских и сельских школ, сравнивая их подходы и преАложения по развитию гуманистической формы взаимоотношений между участниками образовательного процесса.

Исследование показало, что существует разница в том, как учащиеся городских и сельских школ видят факторы, которые формируют предметно-предметные отношения, развивающиеся в процессе обучения. Эти особенности следует учитывать при преобразовании.

Кмючевые слова: субъект-субъектные взаимодействия, модернизация образования, субъективность ^ичности школьников, кооперация в образовательном процессе.

\section{Introduction}

Education and science are the two main areas which modern states put a stake on in achieving leading positions in the world. Human capital development is becoming primary resource in interstate competition. The main characteristic demanded by fateful moment from the life determination of a modern man is subjectivity. In accordance with the leading methodological assumptions, personal subjectivity is characterized by the ability of an individual to implement their goals, willingness to master effective methods and means of achieving them, innovative thinking, systematic and persistent self-development and self-actualization. Based on the above, modernization of public consciousness in the framework of improving human potential of the country primarily consists of the formation of personal subjectivity. As follows from socio-pedagogical research, personal subjectivity of a student is developed through the subject-to-subject relationship (Babinova, 2015: 46-47).

Subject-to-subject interaction means the establishment of "cooperation pedagogy", comanagement of the participants in the educational process, by creating conditions that make it possible to realize, feel and accept the fact of personal responsibility of students for their academic and professional performance. The potential of subjectto-subject relations in the development of personal subjectivity is about creating an effective educational space that actualizes the values of self-sufficiency and proactivity in acquiring the necessary knowledge through implementation of democratization and humanization principles of the educational process.
Defining the conceptual ideas of modernization of Kazakhstan's education, the Nation leader N.A. Nazarbayev, noted, 'The emphasis in education is shifting towards the $4 \mathrm{~K}$ model: Development of creativity, critical thinking, communication skills and team work skills' (Nazarbayev, 2018).

Currently, researchers often identify three main elements as the basis for an effective pedagogical interaction process: Positive interpersonal interaction between a teacher and a student; interpersonal interaction, involving the development of attitudes, values, motives and a certain type of communication, ensuring learning of positive behavioral patterns; well-established cooperation process, where its participants become interdependent and become a single system (Linnik, 2013).

Cooperation in the educational process is manifested in a set of significant positive personal development results: in relieving tension during any communication, tolerance, free expression of one's own opinion, inspired emotions, joint solution of current problems or their definition. Nowadays schoolchild more than ever needs this type of preparation for life in society, where people are forced to simultaneously solve the radically different problems of their being (Nelidov, Khamzin, 2018: $44,586)$.

\section{Literature Review}

Use of subject-to-subject approach potential in improving the quality of education is not an absolutely new aspect for science. However, for the post-Soviet countries, at the stage of global social transformations, this approach received a 
new impetus for its development. Reorientation of the educational process from subject-to-object to subject-to-subject approaches resulted in a paradigmatic shift in educational systems. Belarus, for instance, adopted a humanitarian-culturological model. The purpose of education is harmonious and comprehensive development of an individual in accordance with the standards set by the state (Kotlyarova, 2017).

In the Russian Federation, the idea of priority in the pedagogical process of subject-tosubject relationship was implemented through "cooperation pedagogy" by innovative teachers: Sh.A.Amonashvili, I.P.Volkov, E.N.Il'in et al. (Amonashvili, 1990).

In studies devoted to the development of subjectto-subject interaction in the post-Soviet period, emphasis is placed on the communicative aspect of subject-to-subject interactions (A.P.Panfilova, A.V.Dolmatov, A.P.Markov, N.N.Kuzina, A.V.Bykova, etc.). The works justify the impossibility of school democratization process without any changes in the personality of teacher and students. Authors often associate the process of democratization of education with its adaptation to the standards of developed European countries (Murati, 2015).

Specifics of the development of subject-tosubject relations in rural schools were discussed by V.G. Bocharova, A.M. Helmont, A.G. Kornilova, A.E. Korobko, L.V. Bayborodova, L.S. Malkovich, N.A. Morozova, G.F. Suvorov and a number of other authors whose works we relied on in our practical research.

Modern discourses of studying the problem are widely represented in the world practice by the famous works of John S. Drysek, Margaret L. Clark and Harry Mackenzie (Dryzek, Clark, McKenzie, 1989). In particular, Jessica Lindblom in her monograph describes the essence of subjectto-subject interaction from the standpoint of a sociologist (Lindblom, 2015). Alver, Fusun, Kalglar, Sebnem (2015) investigated the influence of this phenomenon on overall development of communication sciences (Alver, Caglar, 2015); Katya Koch identifies the influence of pedagogical subjective theories on the success in immigrants' education (Koch, 2007). The authors draw attention to the created subjectivity of the relationship as an important factor in preparing young people for a happy life in the future (Ley, Nelson, Beltyukova, 2015).

Studies show that a favorable school atmosphere, social support from teachers, classmates, created by the process of relationships subjectivity determines motivation in learning, and solves the problems of children's deviation (Ansong, Okumu, Bowen, Walker, Eisensmith, 2017).

The interdependence between democratization of relationships and the formation of a civic position among students is investigated (Reichert, Chen, Torney-Purta, 2018). A number of scientists are studying the development of the subjective approach in communication in social networks at various levels (interpersonal, group, or with a moderator (Hansson, 2008). Researchers are also considering the question of the relationship between the concepts of "subjectivity" of an individual and its "autonomy" in society (Zagórska, 2011).

With all the diversity of publications, a comparative analysis of subject-to-subject interactions development process in urban and rural educational institutions has not yet found adequate coverage in both domestic and foreign studies.

Modernization of the educational process in terms of integration of the most progressive, from a technological point of view, and environmentally friendly, in terms of maintaining ethnic and cultural identity in the social environment of urban and rural schools, is also a poorly studied area of modern pedagogical and interdisciplinary knowledge.

\section{The purpose of the article}

Analysis of the existing experience of implementing the subject approach in urban and rural schools, identifying the specifics of the process of forming the subjectivity of students in the context of preserving the traditionalism of Kazakhstani society and developing proposals for optimizing school education. Our publication will be of interest to those states that are trying to improve their education and, at the same time, preserve the cultural integrity.

\section{Materials and Methods}

The study, which covered 217 high school students and 40 teachers, used a comparative method, analysis of documents, and survey methods in accordance with the qualitative strategy: questionnaire survey, in-depth interviews of schoolchildren and experts from urban and rural schools of the South Kazakhstan. When designing the study, authors proceeded from the fact that, by analyzing the practice of implementing a subjectsubject interaction in schools in this region, which is most traditional in terms of its socio-cultural environment, it will be possible to formulate the 
most effective recommendations for improving modernization process of school education in rural areas and optimization of urban education in the traditional Kazakhstani society space. The study was conducted in several stages: first one - in April 2016, second - in October 2016, third - in February 2017. Schoolchildren from ordinary, non-specialized, average schools of South Kazakhstan participated. The sample survey included respondents from the city secondary school No. 102 of the city of Shymkent, students in grades 8-11 between the ages of 13 and 17 . The total number of respondents was 119 pupils (65.5\% - boys, $49.45 \%$ - girls), as well as 98 students living in rural areas (secondary school No. 29 of Sairamsky district, South Kazakhstan region), 7-11 grades students $(43.48 \%$ - boys, $56.52 \%$ are girls) of the same age group (13 to 17 years). The study also involved 20 teachers from the city school No. 102 of Shymkent and 20 rural teachers (school No. 29 of Sairamsky district of the South Kazakhstan region), with teaching experience exceeding 10 years.

\section{Results}

Analysis of the success of implementation of subject-to-subject relationship, the formulation of problems and ways to solve them, from the point of view of the students themselves and their teachers, provides an opportunity to conceptualize further improvement of the educational process in Kazakhstan's schools, development of a modern educational environment while preserving cultural identity and traditionality of Kazakhstan's society, especially those manifested in the South Kazakhstan region. It is the traditional nature of Kazakhstani families, their focus on the preservation and revival of family and educational traditions that creates a specific educational environment in which subject-to-subject relationship can be filled with deep educational potential. It is important to use it correctly. We applied survey methods that make it possible to identify the views of participants in the educational process on ways to optimize the learning process.

A survey of schoolchildren for what motivates them more to actively participate in the learning process and self-development, and also what should change in it in order to optimize, revealed the following set of opinions and assessments.

Most of the urban schoolchildren want to enhance problematicity of learning, its emotionality; they are interested in solving intractable and practiceoriented tasks, where they could express themselves; only $22.7 \%$ of respondents were undecided.
Opinions of students in the rural region look different. Here, a leading factor in active interaction for students is the skillfully organized group work, as well as teachers mastering technical innovations. A significant part of the respondents (20.41\%) consider the competent teacher's use of multi-level assignments (exercises that function as training), interactive participation therein, which continues at home. One third of the students (30.61\%) associate the process of subject-to-subject relationship development using group work in addressing any problem, even personal problems. To a greater extent than urban schoolchildren, they have an interest in team work organized by the teacher. Along with this, schoolchildren to a greater degree demonstrate responsibility for the common cause and training outcome in organizing teamwork. Meanwhile the teacher plays a paternalistic role.

Urban culture influences the teacher's status, who, to a greater extent, should simply be an authoritative expert here. When answering the question: "What do you need from a teacher so that you'd want to study well?" - almost all urban schoolchildren, above all, emphasized professionalism ("strong teacher" $-91.6 \%$ of the choice).

According to surveys, rural school students more often chose spiritual and moral qualities in addition to their professional abilities to present the material. They are described as empathetic, ready to help at any time.

According to the results of in-depth interviews with teachers of urban and rural schools, the most widely used forms of students' subjectivity development were clarified with the help of a special educational process management.

For example, in urban schools, about $35 \%$ of the time is given to the implementation of the multilevel courses method, and the same amount - to implementing "protective exercises" and psychological training sessions. The remaining lesson time is devoted to problem solving group work in pairs.

In the rural region, teachers pay much more attention to the most productive group work (about $45 \%$ are "working in small groups" and 10\% "working in pairs"). The remaining part of the lesson is usually devoted to consolidating exercises and "stress-relief activities".

Urban students, when answering the question: "What role would you play for your teacher?" ("Friend, guardian, psychologist, coach, leader, close person"), for the most part chose the definition of a "leader" (69.62\%). For them, the mobilizing role of a teacher who teaches to "fight for a place in society" by example is more important. 
In contrast to urban schoolchildren, rural school students combine all the roles together. But to a greater degree they associate the image of a teacher with a "close person" $-25.51 \%$, a friend $18.37 \%$, a psychologist $-20.41 \%$. In the teacher's value definition, rural students are dominated by human qualities, spiritual claims to their teacher, who is close to the role of a parent, or a spiritual mentor.

What place do students give to school teachers in their future life achievements? On a 1 to 10 scale, respondents were asked to answer the corresponding question (Table 1).

Rural students see the crucial role of a teacher in their own welfare. Direct contact with the teacher and his/her active participation in the future fate is extremely important for them, almost as that of a father. They prefer "collective cooperation and mutual assistance" rather than competitive struggle in solving all related problems, explaining that "competition" "pressures" and results in intense, insincere relationships" (65.0\%).

Table 1 - Role of schoolteachers in the success of students throughout their lives

\begin{tabular}{|c|c|c|}
\hline \multicolumn{2}{|c|}{ School } \\
\hline Points & City (\% of respondents' choice) & Rural (\%of respondents' choice) \\
\hline 1 & $4.2 \%$ & $0 \%$ \\
\hline 2 & $0 \%$ & $0 \%$ \\
\hline 3 & $32.76 \%$ & $0 \%$ \\
\hline 4 & $0 \%$ & $0 \%$ \\
\hline 5 & $0 \%$ & $7.8 \%$ \\
\hline 6 & $11.76 \%$ & $0 \%$ \\
\hline 7 & $11.76 \%$ & $32.02 \%$ \\
\hline 8 & $35.32 \%$ & $0 \%$ \\
\hline 9 & $0 \%$ & $27.54 \%$ \\
\hline 10 & $4.2 \%$ & $32.64 \%$ \\
\hline
\end{tabular}

Survey methods revealed that laziness of both urban and rural students is a considerable barrier to the development of subject-to-subject relationship in a present-day school, which, by the way, the students themselves recognize. Responding to a question about students managing their free time, the respondents self-critically identified the factors that contribute to its unproductive use (Table 2).

Table 2 - "I would have had more time if..."

\begin{tabular}{|c|c|c|c|c|}
\hline \multicolumn{5}{|c|}{ School } \\
\hline Item № & Urban & $\begin{array}{l}\text { (\%of respondents' } \\
\text { choice) }\end{array}$ & Rural & $\begin{array}{l}\text { (\%of respondents' } \\
\text { choice) }\end{array}$ \\
\hline 1 & ...I wasn’t so lazy & $36.12 \%$ & $\begin{array}{l}\text {...I don't think about it and I don't } \\
\text { want to think about it; I don't care }\end{array}$ & $24.48 \%$ \\
\hline 2 & $\begin{array}{l}\text {...teachers gave us } \\
\text { less home assignments }\end{array}$ & $31.92 \%$ & ...for the Internet & $20.40 \%$ \\
\hline 3 & $\begin{array}{l}\text {...there was less } \\
\text { homework }\end{array}$ & $15.96 \%$ & $\begin{array}{l}\text {...I knew in advance how to spend it } \\
\text { with more use }\end{array}$ & $15.3 \%$ \\
\hline 4 & ...we slept less & $16.00 \%$ & $\begin{array}{l}\text {... not for house work and taking } \\
\text { care of my family }\end{array}$ & $16.32 \%$ \\
\hline 5 & - & - & ...not for extra classes in school & $12.24 \%$ \\
\hline 6 & - & - & ...I lack it & $11.26 \%$ \\
\hline
\end{tabular}


What recommendations for improving educational process are given by the participants themselves? To set a more democratic tone, $75.0 \%$ of teachers in urban and rural schools (their opinions did not differ fundamentally) noted that it was necessary to revise the educational standard, to remove, in their opinion, "irrelevant subjects" that do not play a significant part in development. Unfortunately, "social studies" and "religious studies" were included in this list. The essential underestimation of the educational potential of social sciences is obvious.

Recommendations of schoolchildren look a little different. More than a third (30.84\%) of urban schoolchildren generally found it difficult to answer; $20.76 \%$ of them suggested canceling grades as a type of education control, $27.56 \%$ want to receive most of the teaching material in class, and not during self-directed learning; $12.84 \%$ said that "teachers talk too much"; eight percent of respondents suggested making each lesson unique and interesting, multiplying the number of oral tasks for language development.

The following proposals dominated in the responses of rural students: to introduce more cognitive test tasks into educational process (almost $40 \%$ of respondents); $32.02 \%$ suggest enhancing the knowledge component of classes (the following statement was typical: "pay more attention to acquiring knowledge in the class rather than to the form of a lesson"); $4.03 \%$ each received suggestion "to have classes outdoors", "it is necessary to make each class interesting", "to repeat the material covered more often". No innovative proposals came from students.

Note that innovation in the educational process in schools should transform the fundamental nature of Kazakhstan's education into a fundamental nature of self-education (which is the strength of the modern graduates' training). Both urban and rural schools can equally contribute to the goal. But for this it is important to provide equal chances to the urban and rural regions: possession of a pedagogical asset with high professional and personal competences. The study confirmed that the fundamental nature of each school lesson is determined by systemic knowledge, genral knowledge, and only empathic interaction, organized by a children-loving teacher, making subject-to-subject interaction the norm of communication.

The study also showed that students from urban and rural schools view the factors that form subject-to-subject relationship differently. In urban schools, democratization of educational process is associated with the development of individualism and competition. In rural schools, students are more appreciative of the collectivist communication type, and not the leadership, but, above all, spiritual and moral qualities of teachers who are able to organize friendly group work and a pedagogically supportive environment.

\section{Discussion}

According to Kazakhstani researchers, the most important feature of the development of modern Kazakhstan is its traditionalism. The bearers of traditionalism, its revival, preservation and (in some cases) augmentation are Kazakh families, where, like all Eastern nations, the eldest has always been the most respected and honored person. "Bearers of the spiritual values of the Kazakh people were aksakals, folk musicians, singers, poets and narrators who were called "ustaz", which meant both a teacher and a wise mentor. In Kazakh society, education put a person in a special position and almost always meant a high social status... "Standards of behavior in the family, respect for elders, a sense of duty towards elders and family and tribe were instilled in children from birth. Kazakhstani psychologist, M.P. Kabakova, conducted social and psychological analysis of life values of the Kazakh ethnic group (Kabakova, 2018:.65-67) revealed that for modern Kazakhs, just as before, the most important values are family, children, wellbeing of their family and friends.

According to the study, it justified and proved the family-centeredness of the Kazakh ethnos, orientation of the upbringing traditions to preserving the values of family-kinship ties, maintaining the symbiotic nature of the relationship between parents and children, especially in the families of rural Kazakhs. In the urban Kazakhs families, children are given a little more freedom and independence, while the father traditionally has a dominant role in upbringing. In Russian families, as shown by her study, there is spousal orientation of relationships in the family, and symbiotic character is more pronounced in the relationship between mother and children. Similar results were obtained by Russian researchers (Savinkov, Baklanov, 2017:50). How does this traditionalism of social and cultural field of Kazakhstani society are reflected in the functioning of school education?

A study conducted by the authors of the article revealed that in urban schools students have more developed features of individualistic culture; they are prone to greater freedom in choosing positions and judgments; they are capable of independent 
judgments, self-learning, more than rural schoolchildren; they need problematizing training that forms state-of-the-art knowledge. For urban schoolchildren, the authority figure is a professional teacher, a leader. This characteristic reflects manifestation of present-day beginnings in the educational activities of school. At the same time, the theoretical work of Morton Deutsch (1949) in the middle of the last century had shown that collectivist culture has advantages when it comes to building an atmosphere of cooperation. When comparing the effects of rivalry (individualistic culture) and cooperation (collectivist culture), researchers point to a poor mental health of individualists.

Obviously, speaking about the prospects of harmonization of the educational process in urban schools, ensuring its proportionality to the peculiarities of the socio-cultural life of Kazakhstan's society, in the learning process it is necessary to make provisions for the implementation of techniques to develop collectivist qualities in students development of cooperation skills, teamwork skills, and mutual assistance (Panfilova, 2014). Otherwise, our children will feel their "otherness", and confront the core values of their traditional culture.

For Kazakhstan's society, it is important to achieve a balance in the formation of collectivist and individualistic personality traits. Based on a comparative analysis of the essence of individualistic and collectivist cultures (Triandis, 1989), we note that a school, like any organizational structure, can and is able to, for the benefit of stability in the society, maintain a balance of personal subjectivity and social responsibility.

For urban schoolchildren, it is important to focus the lesson planning strategy on the development of such important collectivist traits as devotion to the spiritual values of culture, altruism, sacrifice, tolerance, social solidarity, both during educational process and during extracurricular time. Experimental data confirm this possibility of effective "nurturing" of collective traits with a systematic, mutually beneficial group interaction of the participants (Anna, 2013).

The study showed that students in the rural region, on the contrary, lean toward collective work. Implementation of subject-to-subject relationship in the framework of modernization of the educational environment of rural schools should include, to a greater extent, learner-centered, tailored education, which differs in urban and rural schools by its orientation.

Through an individual approach in a collectivist environment, it is easier to develop a creative element, to create conditions for the development of leadership qualities and personal autonomy. In the process of teaching rural schoolchildren it is necessary to provide extensive introduction to urban subculture. Psychologically, they must be prepared for self-creation and an independent and active position in life. Students in rural schools should be profoundly aware of what life-sustaining activity means in urban areas and why it is necessary to respect and appreciate life in the country (McCracken, Barcinas, 1991).

For rural schoolchildren, development of certain positive traits of individualistic culture, such as personal responsibility for work, active manifestation of personal initiative, ability to defend one's rights and point of view, ability to first of all rely on one's own strength. In our opinion, this is a priority task for the rural region of the republic and an important step towards modernization of the rural socio-cultural environment.

According to the study, the essence of "equality" in the relationship between the teacher and the students is, first of all, in their mutual respect. As was mentioned earlier, in the traditional culture of family upbringing of the Kazakhs, it is common for a father, the man, to dominate in this process, as he is primarily responsible for maintaining family-related traditions, and building symbiotic relationships with the children. This circumstance should be taken into account in the system of education management, $-\mathrm{a}$ purposeful policy is needed to attract talented men to teaching activities, taking into account the specifics of the formation of a subjective educational space in the Kazakhstan's school.

It is obvious that formal, command methods in the teaching process have a negative impact on the daily process of an educational institution. They have to give way to a clever system of the educational process management, where students, together with teachers, solve everyday problems of the school. The experience of outstanding teachers shows that the emotional contact between a teacher and their student helps to accomplish this task (Semenov, 2013).

But it must be borne in mind that authoritarian methods are not excluded forever from the management process in case of subject-to-subject interaction. This is not always the worst management approach. We need to be realistic. In a class where there is no organizational culture, there is no order, and the values of educational work are not emphasized in the interaction process, the teacher is forced to resort to exceptional methods in order to develop stable moral standards of conduct. 


\section{Conclusion}

With the help of subject-to-subject relationship, one of the most important tasks in the modern process of education and training is to form actual personality behavioral traits in the new generation of students that would allow them to master new social spaces with interest, to be successful both in work and communication, development of new knowledge, to build friendly and family relationships with joy, to be positive participants in the modern life of Kazakhstan society.

For urban schoolchildren, it is important to direct the classes planning strategy to maintain such significant characteristics for the Eurasian culture of Kazakhstan as tolerance, social support and solidarity. For rural students, development of certain positive traits of an individualistic culture, such as personal responsibility, initiative and pro-activity through a subject-to-subject process is relevant. Further development of students' subjective position based on the tradition of honoring the elders, preserving family ties of kinship, family orientation of raising children who still remain in the studied region of Kazakhstan, allows one to successfully achieve their goals in Kazakhstani school in the most environmentally friendly way.

The leading role in further modernization of the educational environment of Kazakhstani schools should be played by the subject-to-subject paternalistic-type relationship, taking into account the specifics of the traditional socio-cultural environment of Kazakhstan, based on respect for elders, honoring the education and wisdom of a mentor. The point of modernization of teacherstudent interaction in the Kazakh school should, on the one hand, be maintaining a certain spiritual distance based on teacher's authority, and on the other hand - showing greater empathy, kindness and involvement in the results of students' learning activities. A present-day teacher is an expert, wellversed in the trends of modern society, able to accompany development of successful life strategies of their students, their desire for self-improvement, hard work, while possessing the emotional intelligence and cultural conformity of the spiritual foundation of their people.

\section{References}

Alver K., Caglar S. (2015). The impact of symbolic interaction on research studies about communication science. International Journal of Arts \& Sciences, Vol. 8, no 7, pp. 479-484.

Amonashvili Sh. A. (1990). Lichnaya I gumannayaosnova pedagogicheskogo processa [Personal and humane basis of the pedagogical process]. Minsk: University publishing house, $560 \mathrm{p}$.

Anna V. B. (2013). Analiz sociokulturnoi I socialno-psihologicheskoi prirody obrazovatelnogo processa [Analysis of Socio-Cultural and Socio-Psychological Nature of the Educational Process]. Procedia-Social and Behavioral Sciences, Vol. 86, pp. $277-282$.

Ansong D. (2017). The role of parent, classmate, and teacher support in student engagement: Evidence from Ghana. International Journal of Educational Development, Vol. 54, pp. 51-58.

Babinova N.V. (2015). Subekt-predmetnie otnosheniya kak uslovie organizacii propektnoi deyateknosti doshkolnikov [Subjectto-subject relations as a condition of project activities organization for preschool children]. Teacher education in Russia, no 4, pp. 46-47.

Dryzek J.S., Clark M.L., McKenzie G. (1989). Subject and system in international interaction. International Organization, Vol. 43, no 3, pp. 475-503.

Hansson T. (2008). Handbook of Research on Digital Information Technologies: Innovations, Methods, and Ethical Issues: Innovations, Methods, and Ethical Issues. IGI Global, $256 \mathrm{p}$.

Kabakova M.P. (2018). Psihologicheskie osobennosti kazahskoi sem'i [Psychological peculiar characteristics of a Kazakh family]. Almaty: Kazakh University, 288 p.

Koch K. (2007) Subjective theories of teachers and their impact on second language acquisition of immigrant children. European Conference on Educational Research, University of Ghent, 19-21 September 2007. Retrieved from: http://www.leeds.ac.uk/ educol/documents/166860.htm (Viewed: 31.03.2018).

Kotlyarova I.V. (2017). Belorusskoe obshestvo v kontekste civilizacionno - kulturnogo koda (sociologicheskoe izmerenie) [Belarusian society in the context of civilization-cultural code (sociological dimension)]. Minsk, Belaruskaya Dumka, $392 \mathrm{p}$.

Ley J., Nelson S., Beltyukova S. (1996). Congruence of Aspirations of Rural Youth With Expectations Held by Parents and School Staff. Journal of Research in Rural Education, Vol. 12, no 3, pp. 133-141.

Lindblom J. (2015). Embodied social cognition. Berlin: Springer, Vol. 26, 235 p.

Linnik E.O. (2013). Sushnostnaya harakeristika koncepcii "subekt - subektnoe vzaimodeistvie"; psichologo - pedagoficheskii aspect [Essential characteristic of the "subject-to-subject interaction" concept: psychological and pedagogical aspect]. Innovative educational technologies, Vol. 36, no 4, pp. 48-54.

McCracken J. D., Barcinas J. D. T. (1991). Differences Between Rural and Urban Schools, Student Characteristics, and Student Aspirations in Ohio. Journal of Research in Rural Education, Vol. 7, no 7, pp. 29-40. 
Murati R. (2015). Conception and Definition of the Democratization of Education. Journal of Education and Practice, Vol. 6, no 30, pp. 173-183.

Nazarbayev N.A. (2018). Address from the President of the Republic of Kazakhstan to the people of Kazakhstan on January 10, 2018. Retrieved from: http://www.akorda.kz/en/addresses/addresses_of_president/poslanie-prezidenta-respubliki-kazahstan-nnazarbaeva-narodu-kazahstana-10-yanvarya-2018-g (viewed: 15.02.2020).

Nelidov S.N., Khamzin A.A. (2018). Ekosfera reprodukcii cheloveka [Ecosphere of human reproduction]. Almaty: named by Volkova N.A., 804 p.

Panfilova, A. P. (2014). Vzaimodestvie uchastnikov obrazovateknogo processa. Uchebnik dlya bakalavrov [Interaction of participants in the educational process: textbook for bachelor students]. M.: Yurayt Publishers, $487 \mathrm{p}$.

Reichert F., Chen J., Torney-Purta J. (2018). Profiles of Adolescents' Perceptions of Democratic Classroom Climate and Students' Influence: The Effect of School and Community Contexts. Journal of youth and adolescence, Vol. 47, no 6, pp. $1279-1298$.

Savinkov V.I., Baklanov P.A. (2017). Spros I ocenka kachestva obrazovaniya naseleniya. Nauchnaya publikaciya [Demand and assessment of the quality of education by the population. Scientific Publication]. Edited by Acad. G.V. Osipova. Moscow: Institute of Social and Political Studies of the Russian Academy of Sciences, $296 \mathrm{p}$.

Semenov M.D. (2013). Pedagogicheskoe obshenie: cennosti I tradicii [Pedagogical communication: values and traditions]. Alma mater (Higher School Bulletin), no 3, pp. 25-27.

Zagórska W. (2011). Subekt - subektnie otnosheniya kak znachimi aspect lichnostnogo razvitiya vo vzroslom vozraste [Subjectsubject relationship as a significant aspect of personal development in adulthood]. Polish Psychological Bulletin, Vol. 42, no 4, pp. 181-187. 